
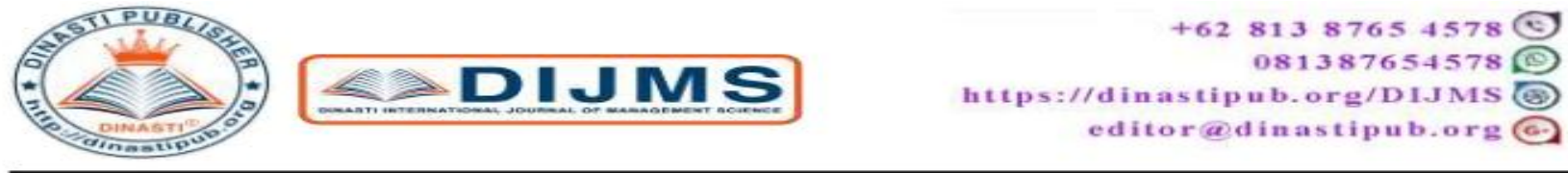

Volume 1, Issue1, September 2019

E-ISSN : 2686-522X

P-ISSN : 2686-5211

\title{
THE ROLE OF ACCOUNTING INFORMATION SYSTEMS, THREATS AND CONTROL STEPS IN FACING GLOBAL MARKET COMPETITION IN PT. XYZ
}

\section{Caecilia Cahyaningsih Kristilestari \\ Master of Accounting, Mercu Buana University Jakarta, Indonesia}

ARTICLE INFORMATION
Received : 01/09/2019
Revised : 11/09/2019
Issued: 21/09/2019
E-mail: caeciliacahyakristi@gmail.com

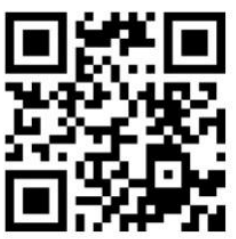

DOI:10.31933/DIJMS
Abstract: Currently the global market is a good and attractive choice for companies to develop themselves, but it is not easy to be able to penetrate the global market let alone to survive in it. The fact that is mostly found in the field is that many companies cannot survive and are able to compete successfully in the global market. Companies that enter the global market must be able to face a competition or competition. In efforts to deal with global market competition, many businesses can be done by companies, one of which is by using information systems. It should also be noted that information systems are not only a solution, but can also be a threat to companies when their control systems are not properly implemented. Then there needs to be an adequate and ready control system in the face of threats. The purpose of the research and writing of this paper is to find out about the use of accounting information systems their role in dealing with global market competition, including the threats that accompany and how to control them within the company. For this information system, the author tries to explain the possible threats, as well as design controls for mitigating these threats. The author uses the name PT.XYZ to describe the existence of the company. The research method used is a qualitative method, the writer tries to provide an explanation using analysis of various sources of literature.

Keywords: System, Information, Accounting, Threats, Control. 


\section{INTRODUCTION}

Information is one of the business resources in a company. Just like other business resources, such as raw materials, labor, capital, information is a very important resource in this modern era. Every day information is received by the company or in this case management as the decision holder and leaves the company to outside parties such as customers, suppliers and stakeholders. Information systems are able to change the shape of the organization, are able to change the way companies operate, and are able to change companies in competing (Alter, 1996). Information is now seen as a strategic resource, a potential source of competitive advantage (Raghunathan and Raghunathan, 1988; Laudon and Laudon 1991) or as a strategic weapon for gaining competitive advantage in the new business climate (Ives and Learmonth, 1984). This shows that information systems play an important role in the company. By utilizing information systems, it is expected that a company can explore its full potential in an effort to achieve excellence in business competition.

Rapidly developing information technology makes information available throughout the world. The rapid information technology is an access for many investors to enter the capital markets around the world, which is not obstructed by national boundaries and this drives the complexity of the challenges that companies must face in the global market.

The company in this paper referred to as PT. XYZ is a growing company, which is trying its luck in the global market arena. This company is engaged in manufacturing. The purpose of the research is because the information system has been widely used in various types of industries, especially in the manufacturing industry which has the most complex activities among other types of industries.

The information system that is developing at this time cannot be separated from the threats that accompany it. Nevertheless, the user can control the threats that may occur in the company's operations. For these threats, mitigation needs to be done through effective controls, so that the operations of PT. XYZ can minimize threats and achieve its goals to be able to survive in the global market.

\section{LITERATURE REVIEW}

\section{Definition and Types of Information Systems}

Understanding the system is a network of procedures that are interconnected, gathered together to carry out an activity or to complete a particular goal, Jogiyanto (2005). Meanwhile, according to Edhy Sutanta (2009), the system in general can be defined as a collection of things or elements that work together or are connected in certain ways so as to form a unity to carry out a function to achieve a goal. The system has certain characteristics or characteristics, namely: System Components, System Limits, External Environment Systems, System Connectors, System Inputs, System Outputs, System Processing and System Objectives.

Understanding of information according to Jogianto (2004), in his book entitled Analysis and Design of Information Systems, believes that information is data that is processed into a form that is more useful for those who receive it. Meanwhile, according to Lani Sidharta (1995), information is data presented in a form that is useful for making decisions. And according to George H. Bodnar (2000), information is data that is processed so that it can be used as a basis for making the right decision.

Based on the understanding of the system and the understanding of the information itself, it can be drawn understanding of the Information System, which is a set of two or more 
interrelated and interacting components that have the ability to process facts from data that has been processed that has uses for its users in the decision making process.

Information systems can be defined as a system within an organization that is a combination of people, facilities, technology, media procedures and controls aimed at obtaining important lines of communication, processing certain types of routine transactions, giving signals to management and others. on internal and external events that are important and provide a basis for information for decision making, Hapzi (2019).

There are various types of information systems that we know so far, including management information systems, executive information systems, accounting information systems, financial information systems, manufacturing information systems, human resource information systems, and marketing information systems. In this article we will discuss accounting information systems related to industries or manufacturing companies in the global market.

\section{Understanding of Accounting}

Some understanding of accounting according to the expert are as follows:

1. Accounting according to ABP Statement No. 4 in Smith Skousen

Defining Accounting is a service activity which is to provide quantitative information, especially those that have the nature of making economic decisions in making decisions that are logical choices among various alternative actions.

2. Accounting according to the Financial Accounting Standards Board (FASB)

Accounting is a service activity whose function is to provide quantitative information which is then used for economic decision making.

3. Accounting according to Donald Kieso, Jerry Weygandt and Terry Warfield

Accounting may be best defined as identification, measurement and communication of financial information about economic entities to interested persons.

4. Accounting according to Warren Reeve

Accounting is an information system that provides reports to stake holders about economic activities and conditions of a business.

5. Accounting according to AAA (American Accounting Association)

Accounting is the process of identifying, measuring and communicating economic information to permit information judgment and decisions by users of the information.

6. Accounting according to Henry Simamora

Accounting is the process of measuring the economic activity of an entity in units of money and communicating the results to interested parties.

\section{Understanding of Accounting Information Systems}

On the understanding of the Information System and the understanding of Accounting above can be drawn about the understanding of the Accounting Information System, which is an information system that produces a report that is needed by parties who have an interest in an economic activity and condition of a company. The following are some meanings of accounting information systems according to some management, accounting, and also experts of information systems:

1. Wilkinson (1991)

Wilkinson (1991) Accounting information system (SIA) is a framework for coordinating resources (data, meterials, equipment, suppliers, personal, and funds) to convert inputs in the 
form of economic data to outputs in the form of financial information used to carry out an entity's activities and provide accounting information for interested parties.

2. Bodnar \& Hopwood (2010)

Bodnar \& Hopwood (2010) said that what is meant by accounting information systems is a collection of various kinds of resources, such as humans and also equipment designed to convert financial data and also other data into information that is useful for users and users.

3. Jogiyanto (2005)

Jogiyanto (2005) says that accounting information systems are a form of information system that converts business transaction data into financial information that is useful for its users.

4. Mulyadi (2008)

Mulyadi (2008) said that an accounting information system is a form of information system that has the objective to provide information for managers of business activities, improve information generated by the existing system, improve accounting control and internal checks, and help to improve clerical costs in maintaining accounting records.

5. Romney \& Steinbart (2006)

Other figures, namely Romney and Steinbart (2006) said that what is meant by the accounting information system is a system that collects, records, stores, and also processes data into useful information in helping the decision making process. Romney (2003) also said that accounting information systems (AIS) can add value to organizations by providing accurate and timely information. A well-designed SIA can do this by:

1) Improve quality and reduce costs to produce products or services

2) Improve efficiency. A well-designed AIS can help improve the efficiency of the running of a process by providing more timely information

3) Improve decision making

4) Sharing knowledge. A well-designed AIS can simplify the process of sharing knowledge and expertise, which can further improve the company's operating processes, and even provide a competitive advantage.

In practice one of the objectives of the Accounting Information System is to provide relevant management information and decision support, as well as improve the ability of lowerlevel managers to make decisions and act strategically, coherently, by the way such information must be easily accessible, of high quality, support management, and increasing the ability to evaluate so that goals are achieved, Bredmar (2014).

\section{Manufacturing company}

According to Heizer (2005), manufacturing comes from the word manufacture, which means making by hand (manually) or by machine so that it produces something. Manufacturing can also be interpreted as activities of processing input into output. Manufacturing activities can be carried out by individuals (manufacturers) or by companies (manufacturing companies). While the manufacturing industry is a group of similar companies that process materials into semi-finished goods or finished goods that have greater added value.

Based on the type of production process or based on the nature of its manufacturing, manufacturing companies are divided into 2 (two) types, viz

1) Companies with types of continuous production processes (continuous process or continuous manufacturing,

2) Companies with intermittent or intermittent manufacturing processes. 


\section{RESEARCH METHODS}

The research method used is a qualitative method, the writer tries to provide an explanation by using analysis of various literatures, or can be called literature studies. The data used are secondary data, which are the results of other parties' research, to then be developed into a descriptive flow of the object under study. In practice, this method is subjective in that the research process is more shown and tends to focus more on the theoretical foundation, with the development of secondary data, to be used as a depiction of what is being studied.

\section{FINDINGS AND DISCUSSION}

From the results the authors want to discuss the influence of leadership styles led to student performance in the event of the activity economic activities of Ecomonic's Care Day, can be explained in table 1. Following:

PT. XYZ as a manufacturing company entering the global market has a response strategy to consumer demand defines how a manufacturing industry company will respond or respond to consumer demand. Basically, the response strategy to consumer demand can be classified into categories: Design-to-Order, Make-to-Order, Assemble-to-Order, Make-to-Stock.

Within a manufacturing company there are several characteristics, including:

1. Product Processing

The company's activities at PT. XYZ are carried out by processing raw materials into finished goods, where the process requires considerable time and effort. The ready goods are then sold to consumers through the marketing process. In Pasarglobal, the marketing media are different, the strategies are also different, this is where the role of the information system works. Information systems set up online marketing, reaching the entire network.

\section{Large Scale Machines}

Production activities in manufacturing companies use machinery and equipment on a large scale in managing the production process so that they can obtain a certain amount of product and quality. However, production activities still require professional human resources to manage the machines and equipment. At PT. XYZ with large-scale machines, the information system works to regulate the production flow that is adequate, timely and guaranteed quality.

\section{Production Costs}

In order to be able to obtain high quality finished products in large quantities, it also requires large costs to assist production activities. These costs are for the supply of raw materials, labor costs, machine maintenance and so forth. PT. XYZ expects that even though the production costs in the industry are very large, the profitability that can be obtained is also very large. Accounting information systems will cut out unnecessary posts, save time, be on target and strongly support low cost and maximum results.

\section{Production Process}

Production activities in manufacturing companies are usually very complete, thus requiring a good division of tasks and organization between divisions. At PT. XYZ, things like the work of the machine operator work to ensure the machine works according to its function, while the quality control department works to ensure that the products obtained are in accordance with SOPs and are suitable for sale to the market.

\section{Marketing and Sales}

Production activities will be closely related to the marketing process and product sales. Without good marketing and sales, the production process will have problems. Manufacturing 
companies usually carry out various kinds of marketing efforts as much as possible so that sales of their products increase rapidly. In fact, companies often incur large costs to carry out promotional activities so that their products are better known to the public and attract consumers to buy.

To support the achievement of the targets set by PT. XYZ, an accounting information system is implemented that can answer the threats that are facing by using adequate controls in business practices.

\section{Threats of Accounting Information Systems in Manufacturing Companies}

Accounting Information Systems have an important role in the governance of organizations or companies. Not infrequently in its implementation there are threats that interfere with the accounting information system, both from internal and external. So it is with manufacturing companies. In the process of its operations, there will be threats in the accounting information system used. Here are some examples of threats to accounting information systems in manufacturing companies, namely:

1. Destruction due to natural disasters or because of political turmoil

Disasters that occur can be classified as natural disasters and political disasters. Natural disasters and political chaos become events that cannot be predicted as a whole. This threat can destroy information systems and cause the collapse of a company. When a disaster occurs in an area, or country, it can even result in the same effect or threat to the overall destruction of the system in an area. Natural disasters are unpredictable factors and have a large effect if they occur in manufacturing companies. Examples of natural disasters include floods, earthquakes, storms, fires and other major natural disasters. The disaster can destroy computer equipment and of course can erase the existing Accounting Information System data. Political disasters can be a threat when political opponents resort to ways to attack corporate information systems.

2. Hardware and Software Damage

Examples of hardware damage are damage to computers and hard drives, which can result in all data being lost and deleting transaction data in the Accounting Information System. Damage can occur due to lack of maintenance or misuse. Software damage can occur due to errors or damage to the software, operating system failures, or errors in sending data that are not detected. In manufacturing companies such as PT. XYZ if this happens it will greatly disrupt operations such as the way orders, product sales and shipping.

\section{Human error}

Inadvertent elements made by humans are possible due to human error. Examples of human errors are incorrect input values into an application because employees are not careful about entering transaction data, errors or deletions due to ignorance, and other errors. At PT. $\mathrm{XYZ}$ this human accident will have fatal consequences for the survival of the company. Input errors or ignorance of deleting data such as order data or order specifications will certainly result in dissatisfaction with the customer. Especially in the global market competition, this will certainly disrupt the company's resilience.

\section{Malware or Computer / System Viruses}

Malware is very vulnerable to occur because of the high activity of data exchange, both externally and internally. Viruses are malware that is often obtained, especially when the acquisition of data from outside parties is still through hardware, such as flash or external hard drives. Threats to malware can also occur when doing access through cyberspace. Malware 
worms and Trojan horses become dominant if the internet user is not careful in accessing the internet, even though the access is safe. These things will threaten the computer which as a medium for the application of the company's accounting information system which directly and indirectly also threatens the application system at PT. XYZ including the database that has been formed.

\section{Human deliberate actions}

Acts of human senateja can be categorized as computer crime. This is usually done by people who understand the gaps in technical security or understand the gaps in the Accounting Information System procedure system. Such intentions can be in the form of sabotage, fraud through computers, misuse of assets, and theft or we can briefly refer to it as fraud. The most common threat that requires more adequate control is human deliberate action. The threat that can occur in the context of human intentions in the accounting information system of PT. XYZ is fraud.

Fraud is a fraudulent act carried out in such a way that it benefits oneself / groups or harms other parties (individuals, companies or institutions). While the reasons for fraud in the context of accounting information systems are of two types, namely: errors or errors and fraud or fraud. Fraud can be interpreted literally as fraud. Fraud like this is an act of cheating intentionally done by someone in such a way that it will be able to benefit themselves / a group / can be detrimental to another party whether it is an individual, a company or an institution. In short, fraud in this manufacturing company, PT. XYZ can be interpreted as cheating related to a number of money, assets and property in its operations.

In dealing with this threat, PT XYZ is trying to prevent and control fraud by having a Good Control System. Regarding internal control, PT. XYZ will follow the internal control framework that has been determined from the Committee of Sponsoring Organizations (COSO), which is as follows: a good control environment, will improve risk assessment more accurately, good control activities, communication flow is more clearly between divisions or divisions and good information and tightened supervision. The short explanation is:

1. Control environment,

Is a work environment created or formed by the company for employees. The elements of the control environment include the following: Management roles and examples, Management communication, proper recruitment of human resources, clear organizational structure, effective internal audit of the company

2. Good communication and information flow (accounting system)

Every fraud that occurs must include fraud, hiding fraud, and conversion. Because a good and right accounting system can provide an audit trail that can help fraud be discovered and make hiding difficult.

A good accounting information system must ensure that transactions recorded include the following criteria: properly authorized or authorized by management. Complete documents, correctly classified, complete documents, reported, properly assessed. Each process is controlled properly and thoroughly by PT. XYZ.

3. Control activities or procedures

In order for employee behavior in accordance with what you want as a businessman and assist the company in achieving its objectives, of course five main control procedures are needed: segregation of duties or dual supervision, authorization system, independent checking, physical security, documents and records, prevent collusion, supervise employees and provide 
telecommunications channels for reporting fraud, creating a picture of the penalties that will be received when committing fraud, carrying out proactive checks.

\section{Types of Control}

The purpose of control is to ensure that activities are completed in ways that lead to the achievement of organizational goals, Hapzi (2019).

In control activities, there are 3 types of control, namely preventive, detective and corrective. Comparison between the three types is as follows: Asalila (2017)

\section{1) Preventive Control}

Namely control activities undertaken to prevent the occurrence of a problem (error condition) of a business process, or in other words control is carried out before the problem arises. This control activity is relatively inexpensive when compared to the other two types of control. In the global market business, preventive control is very necessary, because a company like PT.XYZ must be prepared with all the possible disturbances that come from internal and external companies

Examples of preventive controls:

- Establishment of standard operating procedures for a company's activities;

- The separation of functions within a company is made;

- The range of authorizations within a company is made.

2) Detective Control

Namely control activities carried out in order to find or detect the existence of a problem and look for the root of the problem, or in other words the control is carried out where there has been a problem. These control activities are more expensive than preventive control activities.

Examples of detective control:

- Conduct periodic audits.

- Periodic stock taking is carried out.

3) Corrective Control

Namely control activities undertaken to improve conditions if there is a problem that causes the risk of not achieving the objectives of the organization, which has been found in preventive and detective control activities. Corrective activities are relatively more expensive than inventive and detective activities.

Examples of corrective activities: The improvement of an information system for data errors caused by an error in the information system within the company.

\section{CONCLUSIONS AND RECOMMENDATIONS}

Based on the above discussion, several conclusions can be drawn, namely:

1) PT XYZ requires a reliable accounting information system that is well protected from internal and external threats. Therefore, preventive and selective controls are needed in the implementation of operational processes in the global market.

2) Like information systems in general, accounting information systems also have threats including data entry errors, document / data authorization problems, access to systems outside of the authorities, malware and computer viruses, natural disasters, incorrect recording, and printing of data which is not authorized. So the control is needed not only in the production process but from the initial processing of raw materials to the goods received by the customer. 
3) For these threats, mitigation can be carried out by internal and external reconciliation, validation and authorization strategies in applications, the use of firewalls and antivirus, regulating access control mechanisms, preparing continuity plans for disaster mitigation, and exploration of digital technology.

4) In addition to preventing threats to the accounting information system at PT. XYZ as described above, adequate human resource capacity, the use of information technology, and company commitment from staff to management are needed to achieve the company's targets.

This research has limitations on methods that are only based on literature studies and secondary data acquisition. Further research through primary data and direct research on the implementation of accounting information systems at PT. XYZ is highly expected to be carried out. Based on the limitations of this study, several things that can be recommended include:

1) The existence of strengthening the control of the information system, especially concerning system accessibility and reliability, strategies that must be taken in marketing their products in the global market.

2) Socialization and training on the use of accounting information systems at PT. XYZ is very much needed by company staff who are responsible for each division.

\section{REFERENCE}

Ali, Hapzi. 2019. Definisi Sistem Informasi dan Tinjauan SIA Sistem Pengolahan Transaksi dan Sistem Perencanaan Perusahaan.

Ali, Hapzi, Prof, Dr., Ir., MM, CMA. 2019. Sistem Informasi dan Pengendalian Internal - Sistem Informasi dalam Kegiatan Bisnis Saat Ini

Ali, Hapzi. 2019. Konsep Dasar Keamanan Informasi Pemahaman Serangan, Tipe -Tipe

Pengendalian Prinsip - prinsip The Five Trust Service untuk Keandalan Sistem

Romney, Marshall B., dan Paul John Steinbart. 2003. Accounting Information Systems, Prentice Hall Business Publishing.

Mulyadi. 2008. Sistem Akuntansi. Jakarta: Salemba Empat.

Ikatan Akuntan Indonesia. 2015. Modul Chartered Accountant Sistem Informasi dan Pengendalian Internal. Jakarta: IAI

TMbooks. 2015. Sistem Informasi Akuntansi Konsep dan Penerapan. Yogyakarta: Andi

Bredmar, Krister; Ask, Urban; Frisk, Elisabeth; Magnusson, Johan. 2014. Accounting Information Systems Implementation and Management Accounting Change. Business Systems Research; Zagreb Vol. 5, Iss. 2, (2014): 125-138. DOI:10.2478/bsrj-2014-0015. . Retrifed from https://search.proquest.com/docview/1860825030/92175917EE4E470DPQ/1?accountid=8 $\underline{6413}$

Beard, Deborah; Wen, H Joseph. 2007. Reducing the Threat Levels for Accounting Information Systems. The CPA Journal; New York Vol. 77, Iss. 5, (May 2007): 34-38,40-42. Retrifed from https://search.proquest.com/docview/212229761/D6B08F32A45B422BPQ/1?accountid=8 6413

Easy. Pengertian Akuntansi Menurut Para Ahli. Retrifed from https://learniseasy.com/pengertian-akuntansi-menurut-para-ahli-lengkap/\# (10/10/2019) 
Arri. 2016. Pengertian Industri Manufaktur Menurut Para Ahli. Retrifed from

https://arripple.blogspot.com/2016/04/pengertian-industri-manufaktur-menurut.html. $\underline{(10 / 10 / 2019)}$

Handayanirini. 2005. Analisis Faktor-Faktor Yang Mempengaruhi Minat Pemanfaatan Sistem Informasi dan Penggunaan Sistem Informasi. Retrifed from http://eprints.undip.ac.id/18864/1/RINI_HANDAYANI.pdf. (10/10/2019)

Hastutie. 2001.Peranan Sistem Informasi Dalam menciptakan Keunggulan Daya Saing Melalui Transmigrasi Tehnologi. Retrifed from https://media.neliti.com/media/publications/73370ID-peranan-sistem-informasi-dalam-menciptak.pdf (10/10/2019)

Yuliati, Nurul Hidayati. 2018. Konsep Dasar Keamanan Informasi Pemahaman Serangan, Tipe Tipe Pengendalian Prinsip - prinsip The Five Trust Service untuk Keandalan Sistem. Retrifed from http://nurulhidayati.mhs.blog.mercubuana.ac.id/2018/04/15/konsep-dasarkeamanan-informasi-pemahaman-serangan-tipe-tipe-pengendalian-prinsip-prinsip-the-fivetrust-service-untuk-keandalan-sistem/ (13/10/2019)

Asalila. 2017. Konsep Dasar Keamanan Informasi Pemahaman Serangan, Tipe -Tipe Pengendalian Prinsip - prinsip The Five Trust Service untuk Keandalan Sistem. Retrifed from http://asalila.blogspot.com/2017/05/3-pointer-dalam-sistem-pengendalian.html. $(13 / 10 / 2019)$

Bitar. 2019. 45 Pengertian Akuntansi Menurut Para Ahli (Fungsi, Jenis Dan Tujuan). Retrifed from https://www.gurupendidikan.co.id/pengertian-akuntansi/ (15/10/2019)

Rindu Rika. 2013. Perkembangan Standart Akuntansi Keuangan Indonesia Menuju International Financial Reporting Standards. Retrifed from

https://www.academia.edu/19827425/Jurnal_Akuntansi_Internasional (15/10/2019)

Mahatmyo. 2014. Sistem Informasi Akuntansi Suatu Pengantar. Retrifed ftom https://books.google.co.id/books?hl=en\&lr=\&id=qEI8DAAAQBAJ\&oi=fnd\&pg=PA1\&dq $=$ apa + itu + sistem + informasi,+ancaman + dan + pengendaliannya\&ots $=\mathrm{zHy} 6 \mathrm{yB} 0 \mathrm{kyv} \&$ sig $=\mathrm{KX}$ 7rfS_NtboGupJvpe3pC37GiOM\&redir_esc=y\#v=onepage\&q\&f=false $(15 / 10 / 2019)$

Harry Prabowo. 2015. Pengaruh Sistem Informasi Akuntansi Manajemen, Strategi dan Inovasi Terhadap Kinerja Operasional Perusahaan Memasuki Era Perdagangan Bebas.

Retrifedfrom file://C:/Users/qim2016L2/Documents/Downloads/881-Article\%20Text1492-1-10-20170411.pdf (20/10/2019)

Irma. 2017. Pengaruh Penerapan Sistem Informasi Akuntansi Terhadap Pencegahan Fraudelent Financial Report. Retrifed from http://digilib.mercubuana.ac.id/manager/t!@file_artikel_abstrak/Isi_Artikel_84347063810 5.pdf (20/10/2019)

Ferdiansyah. 2016. Globalisasi Ekonomi, Integrasi Ekonomi Global, Dinamika Pasar Modal \& Kebutuhan Standar Akuntansi Internasional. Retrifed from https://media.neliti.com/media/publications/75776-ID-globalisasi-ekonomi-integrasiekonomi-gl.pdf (20/10/2019)

Kristina Sedyastuti. 2018. Analisis Pemberdayaan UMKM dan Peningkatan Daya Saing Dalam Kancah Pasar Global. Retrifed from http://inobis.org/ojs/index.php/jurnalinobis/article/view/65/55 (20/10/2019)

Usman Bakar. 2009. Implementasi Tehnologi Telekomunikasi Dalam Sistem Informasi Akuntansi untuk Pertukaran Data di Lingkungan Bisnis Global. http://www.jurnal.unsyiah.ac.id/TRA/article/view/313/298 (20/10/2019) 
Elisabeth. 2006. Peranan Akuntansi Global dalam Menghadapi Bisnis Global. Retrifed from http://repository.unpar.ac.id/bitstream/handle/123456789/1561/Orasi_Elizabeth_Peranan_ Akuntansi_Globalp.pdf?sequence=1\&isAllowed=y (20/10/2019) 